\title{
Role of E-Commerce in Reducing Marketing Costs of Industrial Companies in the Hashemite Kingdom of Jordan
}

\author{
Dr.Reem Oqab Hussein Al- Khasawneh \\ Assoc.Prof
}

\begin{abstract}
The study aimed to show the role of e-commerce in reducing marketing costs in the Jordanian industrial companies after the tremendous developments that took place in the commercial fields and the congestion of markets in companies and products and diverse and intensified competition among these companies to achieve profits emerged as one of the modern means of trade that contributed significantly to Changing the future of the business and contributed by facilitating the process of selling and buying electronically to increase the efficiency of companies and strengthen the competitive position and contributed through its role in marketing the company's products electronically to facilitate the process of Obtain products and services by customers at the specified time and speed and reduce the cost of marketing the company's products to a minimum. The researcher used the descriptive analytical method based on the previous studies related to e-commerce and marketing costs and the preparation of a questionnaire distributed to industrial companies to measure the impact of e-commerce on the marketing costs of advertising and promotion costs, storage and distribution costs, sales and distribution costs in industrial companies and the costs of marketing studies and research in companies Jordan Industrial Company. The study found that there is a significant impact on the use and application of e-commerce on the marketing costs of advertising and promotion costs, storage and distribution costs, selling and distribution costs in industrial companies and the costs of marketing studies and researches in Jordanian industrial companies
\end{abstract}

Keywords: Marketing Costs ,E-Commerce,Jordanian industrial companies,E-Marketing

DOI: $10.7176 /$ RJFA/10-20-06

Publication date:October $31^{\text {st }} 2019$

\section{Introduction}

Economic units seek to take advantage of continuous and successive developments of environment of modern works, information technology (IT) and communication techniques, known as e-commerce environment, in order to practice economic activities. In the early 1970s, e-commerce applications were applied; the most famous application applied by huge institutes and companies at that time was e-money transfers. Then, another application known as e-data exchange, was emerged; this application contributed to the expansion of applying e-commerce from mere financial transactions into other transactions; it also increased the number of financial institutes, factories, retailers and service companies which were using this technique.

Practicing economic activities in e-commerce environment has achieved various advantages and benefits; for example, costs of various products have decreased to the lowest level; economic units working in e-commerce environment may achieve a competitive advantage in the markets. Various advantages of using information and communication techniques, especially internet, have undoubtedly encouraged economic units to enter digital environments such as e-commerce entrance. Accordingly, many economic units established websites in order to meet the requirements of modern work environment. Thus, various activities of economic units are practiced in ecommerce environment.

This study identifies the role of using and applying e-commerce in reducing marketing costs of industrial Jordanian companies.

\section{Problem of Study}

Companies seek to reduce the costs of final products to the minimum because of a direct impact of cost reduction of company's sales and profits. Despites of availability of various methods of cost reduction, they may not be effective for some companies.

Emerging e-commerce is one of milestones of technological development of information, reducing the costs, in general and marketing costs, in particular. E-commerce, electronically marketing the products, activates the trade and increases company sales and speediness of marketing the products. In addition, it decreases the time and effort, and reduces the costs of marketing company's products to the minimum. Consequently, it affects greatly the total costs and net profits of the company.

Accordingly, the study aims to answer the following question:

Does using e-commerce in Jordanian industrial companies contribute to the reduction of marketing costs? Importance of Study

The study highlights the nature and essence of relation between study variables, i.e e-commerce and marketing 
costs, and their applied and intellectual connectivity and intermixing.

\section{Purposes of Study}

The study aims at identifying the following:

- The concept of marketing cost which is an integral part of total cost of the final product, the basic tabs and main properties of the costs; and the extent of its impact on total costs and profits.

- The nature of relation between the use of e-commerce and marketing costs and their impact on each other.

- The role of using e-commerce in reducing advertising and promotion costs in Jordanian industrial companies.

- The role of using e-commerce in reducing storage and distribution costs in Jordanian industrial companies.

- The role of using e-commerce in reducing sale and distribution costs in Jordanian industrial companies.

- The role of using e-commerce in reducing the costs of marketing studies and researches in Jordanian industrial companies.

\section{Hypothesis of Study}

The study tests one main hypothesis; it states that there is no a statistically significant relation between the use of e-commerce and reduction of total marketing costs in Jordanian industrial companies. The study also tests the following -hypotheses:

- There is no a statistically significant relation between the use of e-commerce and the reduction of the costs of advertisement and promotion in Jordanian industrial companies.

- There is no a statistically significant relation between the use of e-commerce and the reduction of the costs of storage and distribution in Jordanian industrial companies.

- There is no a statistically significant relation between the use of e-commerce and the reduction of the costs of selling in Jordanian industrial companies.

- There is no a statistically significant relation between the use of e-commerce and the reduction of the costs of marketing studies and researches in Jordanian industrial companies.

\section{Theoretical Framework of Study}

It includes theoretical concepts of e-commerce and marketing costs.

First: E-commerce

a. E-commerce has various definitions developed by the researchers, a set of definitions has been mentioned below: -It is a set of integrated commercial processes performed by all institutes and persons and depend on electronic processing (Redwan, 1999:19).

- It is a new concept explaining selling and purchasing process or product, service and information exchange through computer networks including internet (Murad, 2003:44)

-It is defined in the field of communication as a method which conveys information, services or products via telephone lines, computer networks or any other electronic means (Bassiouni, 2003:76).

-It is defined in the field of service sector as 'a tool which meets the desires of companies, customers and managers to reduce service cost, increase service efficiency and accelerate service conveying (Dempsy, 1997:54).

Despite of availability of various definitions of e-commerce, the researchers have agreed with World Trade Organization (WTO) which defined e-commerce as 'a commercial activity including the processes of producing, promoting, marketing, selling and distributing the products and services via e-communication network' (Najjar, 2002:14).

The researcher believes that e-commerce has contributed to the development of commercial markets which go beyond the limits of time and place, hindering the movement of commercial transactions; e-commerce has created an electronic world and environment which enable the customers to control effectively purchasing process and obtain a required information. In addition, it has based on mutual commercial and service processes, availability of several parts and technological and electronic sides. E-commerce does not require a direct or contact meeting of the parties to make transactions. Accordingly, it has raised the efficiency of performance and has achieved work effectiveness.

\section{b. The parties dealing with e-commerce}

E-commerce transactions are performed by many parties and users of e-commerce; the most important transactions are the following:

- Business to business, also called B to B or B2B, is the oldest form of transactions between businesses; one company uses information technology and communication network for obtaining purchasing orders from the suppliers. (Najjar, 1999:16)

- Business to customer, also called $\mathrm{B} 2 \mathrm{C}$, is performed through the use of internet; various commercial websites, which show all kinds of companies' services and products, are available; the customers can 
purchase and pay by using a credit card or cash on delivery. (Obbins \& Jones, 2000, 39)

- Government to business, also called G2B, is performed by government entities which publish the fees, procedures, regulations, and transaction forms via internet; and the companies can view them electronically (Radwan, 1999:21).

- Government to government, also called $\mathrm{G} 2 \mathrm{G}$, is a form of transactions electronically performed by governmental entities (Noor, 2002, 38).

- Business to government, also called B2G, is a form of electronic commercial transactions in which business units show their works, resources, outputs and their budget; and governmental entities can electronically review these details (Robbins \& Johnes, 2000. 39).

- Customer to customer, also called C2C, is a form of electronic transaction in which a /person sells a product or provide a service to another person via his/ her website (Sha'ban, 2004:49).

- Customer to business, also called C2B, is a form of transactions involving the persons who sell products and services to the companies (www.arablaw.org).

- Customer to government, also called $\mathrm{C} 2 \mathrm{G}$, is a form of electronic transaction including various activities such as payments of taxes and fees (Abdul Hadi, 2000:260).

c. Advantages of E-Commerce

Various advantages are achieved by e-commerce to the companies (Qasraoui, 2001:13).

- Expansion of international and global market due to the reduction of costs;

- Reduction of the costs of creating, processing, distributing, saving and retrieving paper data;

- Establishment of very specialized trades;

- Reduction of the costs of employees working in the companies;

- Reengineering companies' commercial processes;

- Reduction time period between the payment of money and getting the products and services;

- Reduction of the inventory through the withdrawal process performed by supply chain management system;

- Increase of companies' sales;

- $\quad$ Reduction of wire and wireless costs

The advantages of e-commerce to the customers are as follows (Noor,2002:39):

- Understanding customers' needs and availability of many market options;

- Creating a great incentive of competitiveness and developed methods of using e-vouchers and checks;

- Shortening the commercial cycles, reducing costs and time required, responding quickly the customers' needs;

- Participating in virtual auctions;

- Exchanging the experiences and opinions and getting consultations and advices via internet;

The advantages of e-commerce to the society are as follows (Abdulhadi, 2000:261):

- Facilitating the distribution of general services such as health, education and social services at low price and high efficiency;

- Allowing people to possess products which are not available in their home country and get university degrees via internet;

- $\quad$ Allowing the persons to work at home and reduce shipping time; and

- Selling some products at low prices

Second: Marketing Costs:

\section{a. Concept of Marketing Costs}

Institute of cost and management accountants in England identified marketing costs as 'the costs of successive processes which begin with the preparation of the packed product and end with the renewal of the empty packets when they can be reused.' (Al-Bakri, 2002:367) Marketing cost was also defined as 'the costs of storing and transporting the products ready for sale to customers'. (Cannon, 1996:65)

Matz \& Curry defined marketing costs as 'the expenses paid after the costs of manufacturing costs had been paid and the products has been manufactured'. Matz \& Curry, 1972:33)

Accordingly, marketing costs can be defined as 'all costs of marketing activities, including production, advertisement, promotion, storage, distribution, sale, transportation, studies and researches, performed by the companies.'

\section{b.Tabulation of Marketing Costs}

Marketing costs are tabulated by various methods in order to identify the cost of each marketing activity; this process aims at controlling and reducing the costs in a manner that is compatible with company's goals. Thus, Sickle has tabulated the marketing costs as the following: (Sickle, 1974:572)

- Selling expenses including administrative expenses, agent commissions, employees' salaries in sale 
department and insurance and tax expenses.

- Distribution expenses including the costs of storage, employees' salaries, building losses, and shipping, water and electricity expenses.

Moscove believes that marketing costs can functionally be tabulated as the following: (Moscove, 1985:87)

- Financial costs including taxes and insurance;

- Storage costs including building works, auxiliary materials, and cost of warehouse records' keeper;

- Cost of promoting the sales including the advertisement, promotion, and advertisement and marketing researches;

- Cost of collecting orders including the wages of employees who prepare product shipping process;

- Cost of packaging including the process of preparing the product for shipping;

- Costs of distribution and transportation including the costs of transporting and distributing the products to the customers;

- Costs of keeper of the accounts receivable including the cost of preparing and mailing the list, and recording customers' payments; and

- Administrative costs including the expenses of general supervisor, hospitality and preparation.

In addition, marketing costs are classified as the following: (Bakri, 2002: 367)

- $\quad$ Direct marketing costs:

They are the costs related directly to the product, departments, and geographic areas of distribution. For example, packaging costs are direct marketing costs of the product. They also include the costs of advertisement, salaries of sale and security men and all expenses which can directly be connected to a certain distribution area or department.

- Indirect marketing costs:

They are the costs which can be related to more than one entity or activity; they are joint costs incurred on a joint production process performed among distribution areas, products or customers such as the expenses of water, electricity, administration and sale services and sale car extinction;

Moreover, marketing costs can be classified according to the activity and size of the sales as the following: (Rugby, 2003:140)

- $\quad$ Fixed Marketing Costs:

These costs do not change according to the change of sale sized; they are usually related to time such as salaries of managers and employees of sale administration, rent of marketing centres, exhibitions and stores and consumption of sale vehicles, buildings and equipment used.

- $\quad$ Variable marketing costs

They are the costs which change in relation to variations in sale size such as packaging expenses, sale agent commissions, and the costs of shipping and transporting the sales.

Furthermore, marketing costs are classified according to the jobs performed by the organization; each job includes certain costs of activities; this method differs from one company to another according to the number of jobs, company's size and internal organization and available financial resources.

\section{c. Properties of Marketing Costs}

Marketing costs are characterized by the following properties: (Davis, 1961:259)

- Most of marketing cost items are indirect; it is, therefore, difficult to link them to the final product;

- Marketing costs are affected by various external factors such as periods of boom and bust, the change of consumption and competition patterns, the emergence of new products and laws of import and export;

- It is difficult to determine the period of time benefiting from marketing costs;

- It is difficult to measure accurately the productivity of marketing costs;

- It is difficult to segment marketing costs; and

- Methods of analysing and distributing marketing costs are varied as the following:

- Analysis according to production lines;

- Analysis according to sale size; and

- Analysis according to customers.

\section{Methodology of Study}

\section{Population of study}

The population of study is 59 Jordanian industrial companies listed in annual bulletin for 2019 .

\section{Data Resources}

The study has relied on two types of data: secondary data including researches, books, worksheets and official documents of e-commerce and marketing costs and primary data including the data which has been directly collected from field visits to Jordanian industrial companies and the questionnaire designed for achieving this 
purpose.

\section{Data Collection Tool}

A questionnaire has been designed in order to achieve the purposes of the study; it has been arbitrated by five academics specialized in cost accounting. Its final version has consisted of 20 questions for measuring study variables; the questions have been divided into two sections: the first measures the impact of e-commerce and the second measures the impact of e-commerce and the costs of studies. The questionnaire has been distributed to 59 companies, the entire study population; 44 questionnaires have been retrieved; 3 questionnaires have been excluded because they did not include answers to some important statements; 41 questionnaires, i.e $60 \%$ of study population, have been analysed.

\section{Descriptive Analysis}

Respondents' answers have been analysed by using statistical package for social science; the following statistical methods have been used:

-Cronbach's Alpha Test: It tests the internal consistency and reliability of measurement tool.

-Arithmetic means: they identify the rate of response of respondents according to study variables.

-Standard deviations: they are used for measuring the degree of absolute dispersion that represents answers' values.

-One sample T-test: It is used for testing study hypotheses.

\section{Criteria of Descriptive Analysis}

Each set of questions reflecting study hypotheses has been named as a field. For the purposes of data characterization and identification of respondents' opinions on questionnaire's statements and study fields, each statement has been divided according to likert five point scale as the following:

\begin{tabular}{|l|c|c|c|c|c|}
\hline Classification & $\begin{array}{c}\text { Extremely } \\
\text { influential }\end{array}$ & Very influential & $\begin{array}{c}\text { Somewhat } \\
\text { influential }\end{array}$ & $\begin{array}{c}\text { Slightly } \\
\text { influential }\end{array}$ & $\begin{array}{c}\text { Not at all } \\
\text { influential }\end{array}$ \\
\hline Encoding & 5 & 4 & 3 & 2 & 1 \\
\hline
\end{tabular}

According to table above, adopted arithmetic mean is 3; it is extracted from a sum of values which is divided by values' number. Adopted influence ratio is 3 divided by 5, i.e $60 \%$. Accordingly, the values of arithmetic means, reached by the study, are processed in order to interpret the data as the following:

\begin{tabular}{|c|c|c|c|c|}
\hline 1 & 2 & 3 & 4 & 5 \\
\hline Not at all influential & Slightly influential & $\begin{array}{c}\text { Somewhat } \\
\text { influential }\end{array}$ & $\begin{array}{c}\text { Very } \\
\text { influential }\end{array}$ & $\begin{array}{c}\text { Extremely } \\
\text { influential }\end{array}$ \\
\hline $1-1.79$ & $1.80-2.59$ & $2.60-3.39$ & $3.40-4.19$ & $4.20-5$ \\
\hline $\begin{array}{c}\text { E-commerce does not } \\
\text { affect the reduction of } \\
\text { marketing costs in } \\
\text { industrial companies } \\
\text { at all. }\end{array}$ & $\begin{array}{c}\text { E-commerce } \\
\text { affects slightly the } \\
\text { reduction of } \\
\text { marketing costs in } \\
\text { industrial } \\
\text { companies. }\end{array}$ & $\begin{array}{c}\text { E-commerce affects } \\
\text { moderately the } \\
\text { reduction of } \\
\text { marketing costs in } \\
\text { industrial } \\
\text { companies. }\end{array}$ & $\begin{array}{c}\text { E-commerce } \\
\text { affects highly } \\
\text { the reduction } \\
\text { of marketing } \\
\text { costs in } \\
\text { industrial } \\
\text { companies. }\end{array}$ & $\begin{array}{c}\text { E-commerce affects } \\
\text { extremely the } \\
\text { reduction of } \\
\text { marketing costs in } \\
\text { industrial } \\
\text { companies. }\end{array}$ \\
\hline
\end{tabular}

\section{Validity and Reliability Of Study Tool}

Cronbach's alpha coefficient has been used for testing the validity of questionnaire results and an availability of internal consistency among questionnaire statements; an acceptable value of Alpha coefficient is $60 \%$ or more. Alpha coefficient has been applied to all parts of questionnaire; Table 1 illustrates that the value of Cronbach's alpha coefficient of respondents' answers to all questions and fields is higher than the acceptable value. It means that a high degree of internal consistency is available. As a result, study tool has a high level of reliability and its answers can be adopted for achieving study goals and analysing the results. Table below outlines the results of Cronbach's alpha test: 
Table 1 Consistency Coefficients extracted by Cronbach's Alpha

\begin{tabular}{|l|c|c|c|}
\hline \multicolumn{1}{|c|}{ Field } & \multicolumn{2}{c|}{ Results } \\
\cline { 2 - 4 } & $\begin{array}{c}\text { Number of } \\
\text { Question }\end{array}$ & $\begin{array}{c}\text { Alpha } \\
\text { Coefficient }\end{array}$ & Result \\
\hline $\begin{array}{l}\text { Impact of using and applying e-commerce on the costs of } \\
\text { advertisement, storage and promotion in Jordanian industrial } \\
\text { companies }\end{array}$ & $\mathbf{5}$ & $\mathbf{8 7}$ & Accepted \\
\hline $\begin{array}{l}\text { Impact of using and applying e-commerce on the costs of selling in } \\
\text { Jordanian industrial companies }\end{array}$ & $\mathbf{5}$ & $\mathbf{7 2}$ & Accepted \\
\hline $\begin{array}{l}\text { Impact of using and applying e-commerce on the costs of marketing } \\
\text { studies and researches in Jordanian industrial companies }\end{array}$ & 5 & 97 & Accepted \\
\hline $\begin{array}{l}\text { impact of the use of e-commerce on the reduction of the costs of } \\
\text { marketing studies and researches in Jordanian industrial companies }\end{array}$ & $\mathbf{5}$ & 87 & Accepted \\
\hline
\end{tabular}

\section{Data Analysis and Study Hypotheses Testing}

This section discusses the results the field study has reached in the light of study goals, questions and hypotheses.

\section{First -Hypothesis Testing}

In order to validate this hypothesis, arithmetic means and standard deviations have been extracted; the relation between the use of e-commerce and the reduction of the costs of advertisement and promotion in Jordanian industrial companies. Table 2 illustrates the results.

Table 2 : Arithmetic mean and standard deviation of the impact of the use of e-commerce on the reduction of the costs of advertisement and promotion in Jordanian industrial companies

\begin{tabular}{|c|c|c|c|}
\hline Statements & $\begin{array}{c}\text { Arithmetic } \\
\text { mean }\end{array}$ & $\begin{array}{c}\text { Standard } \\
\text { Deviation }\end{array}$ & $\begin{array}{c}\text { Answer } \\
\text { Orientation }\end{array}$ \\
\hline $\begin{array}{c}\text { Using e-commerce contributes to the reduction of the costs of } \\
\text { advertisement of traditional media }\end{array}$ & 4.81 & 0.49 & $\begin{array}{c}\text { Extremely } \\
\text { influential }\end{array}$ \\
\hline $\begin{array}{c}\text { Using e-commerce is one of the most important and inexpensive } \\
\text { promotional means for company's products outside the local } \\
\text { market }\end{array}$ & 4.74 & 0.49 & $\begin{array}{c}\text { Extremely } \\
\text { influential }\end{array}$ \\
\hline $\begin{array}{c}\text { Using e-commerce decreases the salaries, wages and bonuses of } \\
\text { employees in advertisement department }\end{array}$ & 4.79 & 0.49 & $\begin{array}{c}\text { Extremely } \\
\text { influential }\end{array}$ \\
\hline $\begin{array}{c}\text { Using e-commerce decreases the costs of training programs and } \\
\text { courses for the employees of advertisement department in the } \\
\text { company }\end{array}$ & 4.71 & 0.49 & $\begin{array}{c}\text { Extremely } \\
\text { influential }\end{array}$ \\
\hline $\begin{array}{c}\text { The company measures the effectiveness of advertisement, } \\
\text { performed by e-commerce, through the comparison between the } \\
\text { costs of the advertising campaign and its results achieved }\end{array}$ & 4.61 & 0.49 & $\begin{array}{c}\text { Extremely } \\
\text { influential }\end{array}$ \\
\hline Total & 4.77 & 0.49 & $\begin{array}{c}\text { Extremely } \\
\text { influential }\end{array}$ \\
\hline
\end{tabular}

The responses stated above have illustrated that using e-commerce has extremely and positively influenced. In addition, they have showed that using e-commerce contributes to the reduction of the costs of advertisement and promotion in Jordanian industrial companies; total calculated arithmetic mean has been 4.77, which is higher than hypothetical mean which is 3 . Accordingly, responses' orientation has indicated that using e-commerce has extremely influenced.

In addition, arithmetic mean of the statements which form first sub-hypothesis has been compared with standard mark 3 - hypothesis acceptance standard- by using t-test as stated in table 3.

Table 3: Arithmetic Means, Standard Deviations and T-test of Statements which form First sub-Hypothesis

\begin{tabular}{|l|c|c|c|c|c|c|c|}
\hline $\begin{array}{l}\text { The impact of e-commerce on the } \\
\text { reduction of the costs of }\end{array}$ & Number & $\begin{array}{c}\text { Arithmetic } \\
\text { Mean }\end{array}$ & $\begin{array}{c}\text { Standard } \\
\text { Deviation }\end{array}$ & $\begin{array}{c}\text { T- } \\
\text { Value }\end{array}$ & $\begin{array}{c}\text { Freedom } \\
\text { Degree }\end{array}$ & $\begin{array}{c}\text { Statistical } \\
\text { Significance }\end{array}$ \\
\cline { 4 - 9 } \\
advertisement and promotion
\end{tabular}

Table 3 has indicated that there are statistical differences at ) $=0.05$ ) between arithmetic mean and standard deviation 3; T-value has been 10.967; statistical significance has been 0.000 . Thus, the hypothesis, stating that, there is no a statistically significant relation between the use of e-commerce and reduction of the costs of advertisement and promotion in Jordanian industrial companies has been rejected; alternative hypothesis, stating that there is no a statistically significant relation between the use of e-commerce and reduction of the costs of advertisement and promotion in Jordanian industrial companies , has been accepted. 


\section{Second -hypothesis Testing}

In order to validate this hypothesis, arithmetic means and standard deviations have been extracted; the relation between the use of e-commerce and the reduction of the costs of storage and distribution in Jordanian industrial companies. Table 4 illustrates the results.

Table 4 : Arithmetic mean and standard deviation of the impact of the use of e-commerce on the reduction of the costs of storage and distribution in Jordanian industrial companies

\begin{tabular}{|c|c|c|c|}
\hline Statements & $\begin{array}{c}\text { Arithmetic } \\
\text { mean }\end{array}$ & $\begin{array}{c}\text { Standard } \\
\text { Deviation }\end{array}$ & $\begin{array}{c}\text { Answer } \\
\text { Orientation }\end{array}$ \\
\hline $\begin{array}{c}\text { Using e-commerce contributes to the geographic expansion of } \\
\text { distributing company's products }\end{array}$ & 4.81 & 0.49 & $\begin{array}{c}\text { Extremely } \\
\text { influential }\end{array}$ \\
\hline $\begin{array}{c}\text { Using e-commerce decreases the salaries and wages of brokers } \\
\text { and distributors of company's products }\end{array}$ & 4.85 & 0.49 & $\begin{array}{c}\text { Extremely } \\
\text { influential }\end{array}$ \\
\hline $\begin{array}{c}\text { Using e-commerce saves the costs of travelling to the target } \\
\text { markets }\end{array}$ & 4.79 & 0.49 & $\begin{array}{c}\text { Extremely } \\
\text { influential }\end{array}$ \\
\hline $\begin{array}{c}\text { Using e-commerce reduces company's stock, and the salaries } \\
\text { and the wages of warehouse workers }\end{array}$ & 4.81 & 0.49 & $\begin{array}{c}\text { Extremely } \\
\text { influential }\end{array}$ \\
\hline $\begin{array}{c}\text { Using e-commerce decreases the costs of insurance of } \\
\text { warehouses and the expenses of office equipment and the } \\
\text { consumption of equipment used in the stores }\end{array}$ & 4.84 & 0.49 & $\begin{array}{c}\text { Extremely } \\
\text { influential }\end{array}$ \\
\hline Total & 4.85 & 0.49 & $\begin{array}{c}\text { Extremely } \\
\text { influential }\end{array}$ \\
\hline
\end{tabular}

The responses stated above have illustrated that using e-commerce has extremely and positively influenced. In addition, they have showed that using e-commerce contributes to the reduction of the costs of storage and distribution in Jordanian industrial companies; total calculated arithmetic mean has been 4.85, which is higher than hypothetical mean which is 3 . Accordingly, responses' orientation has indicated that using e-commerce has extremely influenced.

In addition, arithmetic mean of the statements which form second sub-hypothesis has been compared with standard mark 3 - hypothesis acceptance standard- by using t-test as stated in table 5.

Table 5: Arithmetic Means, Standard Deviations and T-test of Statements which form second sub-Hypothesis

\begin{tabular}{|l|c|c|c|c|c|c|}
\hline $\begin{array}{l}\text { The impact of e-commerce on } \\
\text { the reduction of the costs of } \\
\text { storage and distribution }\end{array}$ & Number & $\begin{array}{c}\text { Arithmetic } \\
\text { Mean }\end{array}$ & $\begin{array}{c}\text { Standard } \\
\text { Deviation }\end{array}$ & T-Value & $\begin{array}{c}\text { Freedom } \\
\text { Degree }\end{array}$ & $\begin{array}{c}\text { Statistical } \\
\text { Significance }\end{array}$ \\
\cline { 2 - 8 } & 41 & 4.85 & 0.49 & 10.967 & 21 & 000. \\
\hline
\end{tabular}

Table 5 has indicated that there are statistical differences at ) $=0.05$ ) between arithmetic mean and standard deviation 3; T-value has been 10.967; statistical significance has been 0.000 . Thus, the hypothesis, stating that there is no a statistically significant relation between the use of e-commerce and the reduction of the costs of storage and distribution in Jordanian industrial companies ,has been rejected; alternative hypothesis, stating that there is a statistically significant relation between the use of e-commerce and the reduction of the costs of storage and distribution in Jordanian industrial companies ,has been accepted .

\section{Third -Hypothesis Testing}

In order to validate this hypothesis, arithmetic means and standard deviations have been extracted; the relation between the use of e-commerce and the reduction of the costs of storage and distribution in Jordanian industrial companies. Table 6 illustrates the results. 
Table 6 : Arithmetic mean and standard deviation of the impact of the use of e-commerce on the reduction of the costs of selling and distribution in Jordanian industrial companies

\begin{tabular}{|c|c|c|c|}
\hline Statements & Arithmetic mean & $\begin{array}{c}\text { Standard } \\
\text { Deviation }\end{array}$ & $\begin{array}{c}\text { Answer } \\
\text { Orientation }\end{array}$ \\
\hline $\begin{array}{c}\text { Using e-commerce increases the marketing share of } \\
\text { company's sales }\end{array}$ & 4.80 & 0.49 & $\begin{array}{c}\text { Extremely } \\
\text { influential }\end{array}$ \\
\hline $\begin{array}{c}\text { Using e-commerce facilitates the process of selling } \\
\text { company's products in the target markets }\end{array}$ & 4.87 & 0.49 & $\begin{array}{c}\text { Extremely } \\
\text { influential }\end{array}$ \\
\hline $\begin{array}{c}\text { Using e-commerce decreases the salaries, wages and } \\
\text { bonuses of company's salesmen }\end{array}$ & 4.78 & 0.49 & $\begin{array}{c}\text { Extremely } \\
\text { influential }\end{array}$ \\
\hline $\begin{array}{c}\text { Using e-commerce reduces the expenses of sale } \\
\text { management, salesmen travel to the target markets }\end{array}$ & 4.81 & 0.49 & $\begin{array}{c}\text { Extremely } \\
\text { influential }\end{array}$ \\
\hline $\begin{array}{c}\text { Using e-commerce helps the company sell its products } \\
\text { at competitive prices }\end{array}$ & 4.84 & 0.49 & $\begin{array}{c}\text { Extremely } \\
\text { influential }\end{array}$ \\
\hline Total & 4.82 & 0.49 & $\begin{array}{c}\text { Extremely } \\
\text { influential }\end{array}$ \\
\hline
\end{tabular}

The responses stated above have illustrated that using e-commerce has extremely and positively influenced. In addition, they have showed that using e-commerce contributes to the reduction of the costs of selling in Jordanian industrial companies; total calculated arithmetic mean has been 4.82, which is higher than hypothetical mean which is 3. Accordingly, responses' orientation has indicated that using e-commerce has extremely influenced.

In addition, arithmetic mean of the statements which form third sub-hypothesis has been compared with standard mark 3 - hypothesis acceptance standard- by using t-test as stated in table 7.

Table 7: Arithmetic Means, Standard Deviations and T-test of Statements which form third sub-Hypothesis

\begin{tabular}{|l|c|c|c|c|c|c|}
\hline $\begin{array}{l}\text { The impact of e-commerce on } \\
\text { the reduction of the costs of } \\
\text { selling }\end{array}$ & Number & $\begin{array}{c}\text { Arithmetic } \\
\text { Mean }\end{array}$ & $\begin{array}{c}\text { Standard } \\
\text { Deviation }\end{array}$ & T-Value & $\begin{array}{c}\text { Freedom } \\
\text { Degree }\end{array}$ & $\begin{array}{c}\text { Statistical } \\
\text { Significance }\end{array}$ \\
\cline { 2 - 8 } & 41 & 4.82 & 0.49 & 10.967 & 21 & 000. \\
\hline
\end{tabular}

Table 7 has indicated that there are statistical differences at ) $=0.05$ ) between arithmetic mean and standard deviation 3; T-value has been 10.967; statistical significance has been 0.000 . Thus, the hypothesis, stating that there is no a statistically significant relation between the use of e-commerce and the reduction of the costs of selling in Jordanian industrial companies ,has been rejected; alternative hypothesis, stating that there is a statistically significant relation between the use of e-commerce and the reduction of the costs of selling in Jordanian industrial companies ,has been accepted.

\section{Fourth -Hypothesis Testing}

In order to validate this hypothesis, arithmetic means and standard deviations have been extracted; the relation between the use of e-commerce and the reduction of the costs of marketing studies and researches in Jordanian industrial companies. Table 8 illustrates the results.

Table 8: Arithmetic mean and standard deviation of the impact of the use of e-commerce on the reduction of the costs of marketing studies and researches in Jordanian industrial companies

\begin{tabular}{|c|c|c|c|}
\hline Statements & $\begin{array}{c}\text { Arithmetic } \\
\text { mean }\end{array}$ & $\begin{array}{c}\text { Standard } \\
\text { Deviation }\end{array}$ & $\begin{array}{c}\text { Answer } \\
\text { Orientation }\end{array}$ \\
\hline $\begin{array}{c}\text { Using e-commerce decreases the salaries, wages and bounces of } \\
\text { employees working in marketing research department }\end{array}$ & 4.80 & 0.49 & $\begin{array}{c}\text { Extremely } \\
\text { influential }\end{array}$ \\
\hline $\begin{array}{c}\text { Using e-commerce decreases the costs of marketing researches and } \\
\text { studies }\end{array}$ & 4.87 & 0.49 & $\begin{array}{c}\text { Extremely } \\
\text { influential }\end{array}$ \\
\hline $\begin{array}{c}\text { Using e-commerce decreases the bounces and salaries of experts and } \\
\text { consultants of marketing }\end{array}$ & 4.78 & 0.49 & $\begin{array}{c}\text { Extremely } \\
\text { influential }\end{array}$ \\
\hline $\begin{array}{c}\text { Using e-commerce allows the customers to exchange the experiences } \\
\text { and opinions and get any inquiry or consultation }\end{array}$ & 4.81 & 0.49 & $\begin{array}{c}\text { Extremely } \\
\text { influential }\end{array}$ \\
\hline $\begin{array}{c}\text { Using e-commerce meets customers' needs and requirements and } \\
\text { achieves the highest level of customers' satisfaction }\end{array}$ & 4.84 & 0.49 & $\begin{array}{c}\text { Extremely } \\
\text { influential }\end{array}$ \\
\hline Total & 4.82 & 0.49 & $\begin{array}{c}\text { Extremely } \\
\text { influential }\end{array}$ \\
\hline
\end{tabular}

The responses stated above have illustrated that using e-commerce has extremely and positively influenced. In addition, they have showed that using e-commerce contributes to the reduction of the costs of marketing studies and researches in Jordanian industrial companies; total calculated arithmetic mean has been 4.82, which is higher 
than hypothetical mean which is 3. Accordingly, responses' orientation has indicated that using e-commerce has extremely influenced.

In addition, arithmetic mean of the statements which form fourth sub-hypothesis has been compared with standard mark 3 - hypothesis acceptance standard- by using t-test as stated in table 9.

Table 9: Arithmetic Means, Standard Deviations and T-test of Statements which form fourth sub-Hypothesis

\begin{tabular}{|l|c|c|c|c|c|c|c|}
\hline \begin{tabular}{l} 
The impact of e-commerce on \\
the reduction of the costs of \\
marketing studies and \\
\cline { 2 - 8 } \\
researches
\end{tabular} & 41 & 4.82 & 0.49 & 10.967 & 21 & $\begin{array}{c}\text { Statistical } \\
\text { Significance }\end{array}$ \\
\hline
\end{tabular}

Table 7 has indicated that there are statistical differences at ) $=0.05$ ) between arithmetic mean and standard deviation 3; T-value has been 10.967; statistical significance has been 0.000 . Thus, the hypothesis, stating that there is no a statistically significant relation between the use of e-commerce and the reduction of the costs of marketing studies and researches in Jordanian industrial companies ,has been rejected; alternative hypothesis, stating that there is a statistically significant relation between the use of e-commerce and the reduction of the costs of marketing studies and researches in Jordanian industrial companies ,has been accepted.

\section{Results and Recommendations}

Results

Based on statistical analysis, the study found the following results:

- Jordanian industrial companies use e-commerce in products' marketing in order to reduce the costs of the advertisement, the salaries, wages and bounces of the employees working in advertisement department and the expenses of training programs and courses held in advertisement department;

- Jordanian industrial companies use e-commerce in order to decrease company's stocks, the salaries, wages and bounces of the employees working in the warehouses, the expenses of the warehouses, office equipment, and the consumption of machines and devices used in the warehouses;

- Jordanian industrial companies use e-commerce in order to increase the marketing share of companies' products and sell their products at competitive prices;

- Jordanian industrial companies use e-commerce in order to decrease the salaries, wages and bounces of company's salesmen, and the expenses of sale management, and travel of salesmen;

- Jordanian industrial companies use e-commerce in order to decrease the salaries, wages and bounces of employees working in marketing research department;

- Jordanian industrial companies uses e-commerce in order to exchange experiences and opinions and give advices and consultations to the customers;

- Jordanian industrial companies use e-commerce in order to meet the needs and requirements of customers and achieve the highest level of customer satisfaction; and

- Jordanian industrial companies use e-commerce in order to reduce the costs of marketing studies and researches, the salaries and bounces of marketing experts and consultants.

\section{Recommendations}

The following recommendations for research have been based on the study findings:

- Jordanian industrial companies shall raise employees' awareness of e-commerce through holding relevant training programs and courses;

- Jordanian industrial companies shall periodically measure the effectiveness of advertising through holding a comparison between the results of using e-commerce in advertisement and the sums of money spent for this purpose;

- Jordanian industrial companies shall pay attention to the advantages and role of using e-commerce in reducing company's stock, the salary and wages of employees working in the warehouses, the expenses of insurance of the warehouses, office equipment and devices used in the warehouses; and

- Jordanian industrial companies shall conduct researches and studies on the impact of information and communication technology on the costs of marketing and its role in reducing marketing costs.

\section{Arabic References}

- Murad, Abdulfattah, 'Using E-commerce For Selling and Purchasing Online', Wael Printing and Publishing House, Amman, 2003.

- Radwan, Raafat, ' World of E-commerce', Arab Organization For Administrative Development, Cairo, Egypt, 1999.

- Abdulrahman, Ismail, 'Gulf Countries Are Moving towards the Adoption of a Unified Law of Ecommerce’, Kuwait, 2009. 
- $\quad$ Bassiouni, AbdulHamid, 'E-Commerce', Cairo, Dar Al-Ketab For Publishing and distributing, 2003.

- Najjar, Ahmad, 'Problem of Tax Dimension Of E-commerce', Kuwait University, 2002.

- Najjar, Ahmad, 'E-Commerce and Marketing in the light of Globalization', Kuwait University, 1999.

- Shaaban, Abdullah, 'Role of Banks in E-Commerce', Journal of the Union of Banks, No. 28, 2004.

- Qasrawi, Nahla, 'Environment of E-commerce in UAE', First Edition, UAE, 2001.

- Rahhleh, Hazem and Khasawneh, Hazem, ' E-commerce and Its Expected Effects on Revenues in Arab World', Philadelphia University, 2001.

- Noor, Bassam, 'Fundementals of E-commerce', Arab Encyclopaedia of Computer and Internet, 2002, http:||www.c4arab.com

- Abdulhadi, Ibrahim Abdulhafid, 'A Proposed Framework of Tax Amendments Required For Transformation to World of E-commerce', A Theoretical and Field Study, 2000.

- Al-Bakri, Thamer Yasser, ' Marketing Management', First Edition, Al-Dar Al-Jamiyah For Printing and Publishing, Baghdad, 2002.

- Al-Ragby, Mohammad Tayseer, 'Cost Accounting', Wael House For Publishing, Amman, Third Edition, 2003.

\section{Foreign References}

- Dempsy ,Donald, ," what is electronic commerce" ,usa,march,1997.

- $\quad$ http:\| www. Cuarab.com \showac

- Matz \& Curry -“ cost accounting, planning and control ", 5th ed, 1972.

- Moscove, Crowing Shield -“Cost accounting with managerial applications”, fifth edition - 1985.

- Sickle,Clarence,L. , "Cost accounting Fundamentals and Procedures “, 2nd ed, New York,1974 .

- Davis, Kenneth,R. “ Marketing Management “, 3rd ed , Donald press Co ,New York, 1961. 2000. JOENS, DON," E-COMMERCE FOR DUMMIES", NEW YORK , - ROBBINS, STEPHEN\& -http:|| www. Arablaw.org|E-commerce-general.doc

- Cannon, Tom,"Basic Marketing" , 4th, ed, Carrell publishers Limited , London,1996. 